\title{
WOMEN IN TREATMENT FOR ALCOHOLISM IN A BRAZILIAN STATE
}

\section{CAPITAL: SOCIO-DEMOGRAPHIC CHARACTERISTICS}

\section{CLECIA NUNES BEZERRA ${ }^{1 *}$, RODRIGO REBOUÇAS DE CASTRO \& FLÁVIO SOARES ARAÚJO ${ }^{3}$ \\ ${ }^{I}$ Medical Student, State University of Health Sciences of Alagoas, Alagoas, Brazil \\ ${ }^{2}$ Psychiatry Resident, State University of Health Sciences of Alagoas, Alagoas, Brazil \\ ${ }^{3}$ Professor of Psychiatry, State University of Health Sciences of Alagoas, Alagoas, Brazil}

\section{ABSTRACT}

OBJECTIVE

Describe demographic characteristics of women with abuse or alcohol dependence admitted to the Study and Customer Alcohol and other Drugs Addiction Center (CEAAD) of the State University of Health Sciences of Alagoas (UNCISAL) and dropped out.

\section{METHODS}

We included 61 patients treated in CEAAD from 2014 to 2018. The data were collected from medical records. Using as criteria the abandonment of treatment, patients were separated into two groups: $A=$ quick abandonment and $B$ = gradual abandonment .

RESULTS

In both groups there was a predominance of young adult women, living alone, with incomplete primary school and unemployed. For mild and moderate to severe degree of dependence was significantly higher $(p<0.001)$ in groups $A$ and $B$.

\section{CONCLUSION}

Involving women in their bio psychosocial midst is a way to offer better treatment, as well as better investments in prevention. This research showed that patients were generally young adults, alone and unemployed. The level of severe dependence prevails in the population studied.

KEYWORDS: Alcoholism, Female \& Chemical Dependency

Received: May 19, 2019; Accepted: Jun 22, 2019; Published: Jul 10, 2019; Paper Id.: IJMPSAUG20197

\section{INTRODUCTION}

Alcoholism is one of the major public health problems in Brazil. Its consequences is linked to high traffic mortality rates, work distancing, family conflicts, breakdown of relationships and health problems, involving not only those who drinks, but everyone who participates in their family environment (Santos \& Silva, 2012). Much is studied about the relationship between alcoholism and males, but little is known about females. The prevalence of alcoholism among women is still significantly lower relatively to men. Even so, excessive consumption and / or alcohol dependence has many negative impacts on physical and mental health in women (Oliveira, Dell' AGnolo, Ballani, Carvalho, \& Pelloso, 2012). 
For a long time, alcoholism was characterized by male population, with a minimum prevalence of women in specialized health services (Elbreder, Laranjeira, Siqueira, \& Barbosa, 2008). However, this scenario has changed, according to the profile of alcohol consumers, women population became relevant, as evidenced by data from the I National Survey on alcohol consumption patterns of the Brazilian population of 2007 showing that $65 \%$ of men and $41 \%$ of women consume some type of alcoholic beverage (Monteiro, Dourado, Graça, \& Freire, 2011).

Scientific studies reveal that the ingestion of similar amounts, due to the physical characteristics of women, alcohol has a greater negative repercussion in the female organism in relation to male organism. One of the causes is the greater difficulty women have in metabolizing alcohol due to the lower volume of water and the greater proportion of body fat. Thus, causing in women to feel the effects of alcoholic beverages faster than men, requiring smaller portions to achieve the same effects (Esper, Corradi-Webster, Carvalho, \& Furtado, 2013).

The shortage of women in services, presented by the first epidemiological studies, opened a framework of questions that were both the vision of alcoholism as a predominantly male problem to the attempt to investigate this question including social behavior in the face of alcoholism in women (Keller, 1980).

The perception of society in the face of female alcoholism is aggressive, the woman is considered more immoral, suffers from stigmatization, resulting in the search for treatment less frequently, which causes them more commitments with the use (Nóbrega \& Oliveira, 2005).

In order to minimize the consequences of alcohol abuse, it is necessary to reinforce existing public policies, since they are important means to reduce social and economic inequalities, ensuring equitable access to goods and services, including health care. Such policies should be applied to the set of sectors related to determinants of health, focusing on the base of the problem of alcoholism (Silva, Vasconcelos, Padilha, Martini, \& Backes, 2007).

The treatment of alcoholism is complicated, and can occur in specialized services such as Psychosocial Care Center for alcohol and drugs (in Brazil, there they are called by CAPS-AD), as well as in primary care services, outpatient clinics, hospitals and community support groups. Thus, the Ministry of Health proposes coping mechanisms aimed at strengthening the assistance network for alcohol and other drug users, focusing on community care and aimed at the rehabilitation and social reintegration of its users (Ministério da Saúde, 2004).

Using as criteria the abandonment of treatment, Baekland and Lundwall (1975) defined as "early abandonment" those related to patients who remained in treatment until the first month and as "gradual abandonment" those related to patients who remained in treatment for more than one month.

The purpose of this study is to describe the sociodemographic characteristics of women with alcohol abuse or dependence admitted at the Study and Attention to Alcoholism and Other Drug Dependence Center (CEAAD) of the State University of Health Sciences of Alagoas (UNCISAL) who abandoned treatment.

\section{METHODS}

A retrospective cohort study with active search in the medical records of female patients who presented alcohol abuse or dependence, according to CID-10 criteria, assisted at CEAAD, from 2014 to 2018.

The sample included 61 patients, who met the inclusion criteria. Using as a criteria the treatment abandonment, patients were subdivided into two groups. Those who remained in treatment until the first month were included in group A 
$=$ fast abandonment $(\mathrm{n}=40)$ and those who dropped out after this period were included in group $\mathrm{B}=$ gradual abandonment $(\mathrm{n}=21)$

Inclusion criteria were women seeking treatment at CEAAD between 2014 and 2018; who met criteria for abuse/harmful use or dependence on alcohol, according to CID-10 criteria, attended at least one weekly visit, for a period of one month or more, and then dropped out of treatment.

The information was collected through an active search in the medical records of the female patients. The following data were recorded: age; marital status; breed; schooling; profession; frequency of alcohol use in the last month and degree of dependence. The Short Alcohol Dependence Data (SADD), which assesses the presence and severity of alcohol dependence, was routinely applied to users of the service and, according to the sum of the points, the patient could be classified according to the degree of dependence: mild (1-9 points), moderate (10-19 points) and severe (20-45 points). To compare groups, the chi-square test or, when necessary, Fisher's exact test was applied. $\mathrm{P}<0.05$ was considered statistically significant.

\section{RESULTS}

The results of the study are shown in Table 1.

Table 1: Results of the Variables Studied in the Population

\begin{tabular}{|c|c|c|c|c|c|c|c|}
\hline Variables & Group A & $\%$ & Group B & $\%$ & Total & $\%$ & p \\
\hline Age & & & & & & & 0,344 \\
\hline 15-19 years & 6 & 15 & 2 & 10 & 8 & 13 & \\
\hline 20-30 years & 28 & 70 & 16 & 76 & 44 & 72 & \\
\hline $31-49$ years & 3 & 7,5 & 3 & 14 & 6 & 10 & \\
\hline Above de 50 years & 3 & 7,5 & 0 & 0 & 3 & 5 & \\
\hline Marital status & & & & & & & 0,885 \\
\hline Single & 25 & 63 & 14 & 67 & 39 & 64 & \\
\hline Married & 6 & 15 & 3 & 14 & 9 & 15 & \\
\hline Divorced & 7 & 17 & 4 & 19 & 11 & 18 & \\
\hline Widow & 2 & 5 & 0 & 0 & 2 & 3 & \\
\hline Breed & & & & & & & 0,319 \\
\hline White & 25 & 63 & 10 & 48 & 35 & 57 & \\
\hline Brown & 12 & 30 & 10 & 48 & 22 & 36 & \\
\hline Black & 3 & 7 & 1 & 4 & 4 & 7 & \\
\hline Schooling & & & & & & & 0,121 \\
\hline Illiterate & 8 & 20 & 4 & 19 & 12 & 20 & \\
\hline $1^{\circ}$ incomplete degree & 15 & 37,5 & 9 & 43 & 24 & 39 & \\
\hline $1^{\circ}$ full degree & 10 & 25 & 4 & 19 & 14 & 23 & \\
\hline $2^{\circ}$ incomplete degree & 6 & 15 & 2 & 9,5 & 8 & 13 & \\
\hline $2^{\circ}$ full degree & 1 & 2,5 & 2 & 9,5 & 3 & 5 & \\
\hline Profession & & & & & & & 0,322 \\
\hline Maid & 5 & 12,5 & 5 & 24 & 10 & 16 & \\
\hline Unemployed & 18 & 45 & 7 & 33 & 25 & 41 & \\
\hline Student & 4 & 10 & 5 & 24 & 9 & 15 & \\
\hline Housewife & 11 & 27,5 & 4 & 19 & 15 & 25 & \\
\hline Retired & 2 & 5 & 0 & 0 & 2 & 3 & \\
\hline Frequency of alcohol use in the last month & & & & & & & 0,371 \\
\hline Daily use & 16 & 40 & 9 & 43 & 25 & 41 & \\
\hline 5 to 6 days per week & 10 & 25 & 5 & 24 & 15 & 25 & \\
\hline 3 to 4 days per week & 7 & 17,5 & 3 & 14 & 10 & 16 & \\
\hline 1 to 2 days per week & 6 & 15 & 3 & 14 & 9 & 15 & \\
\hline
\end{tabular}




\begin{tabular}{|c|c|c|c|c|c|c|c|}
\hline \multicolumn{8}{|c|}{ Table 1: Contd., } \\
\hline 1 time per month & 1 & 2,5 & 1 & 5 & 2 & 3 & \\
\hline Degree of dependency of SADD & & & & & & & $<0,001$ \\
\hline Mild & 3 & 7,5 & 1 & 5 & 4 & 6,5 & \\
\hline Moderate & 15 & 37,5 & 3 & 14 & 18 & 29,5 & \\
\hline Serious & 22 & 55 & 17 & 81 & 39 & 64 & \\
\hline
\end{tabular}

In both groups, there were no statistically significant differences in socio demographic characteristics. The population assisted is extremely young. These women live without partners and have a low level of education. In regards to race, since the miscegenation of the studied population, it is possible that bias occurs, once the conception of skin-color varies according to those who fills the medical records at the moment of reception. Those considered white prevailed in both groups. Unemployment also prevailed in both groups. However, the patients employed, both in group A and in $\mathrm{B}$, had low remuneration and had no professional records.

There was no statistical significance regarding to frequency of alcohol use in the last month. However, in both groups there was a predominance of daily use. When considering the degrees of mild, moderate and severe dependence, the severe dependence was significantly higher $(\mathrm{p}<0.001)$ in groups A and B.

\section{DISCUSSIONS}

Studies on alcoholism, for the most part, are turned to male population. Most studies on female alcoholism were acquired through research on male alcoholism. However, more studies on the abusive intake of alcohol by women have been published, and consumption has been increasing in the female population (Mendes, Cunha, \& Nogueira, 2011).

Regarding to the relationship with a partner, women who attended in the service were, in $76.3 \%$ of the cases, alone. Consumption of alcohol can lead to dependence, and disorders resulting from excess and irregular intake adversely affect family and interpersonal relationships (Malbergier, Cardoso, \& Amaral, 2012).

The low schooling of the analysed sample reflects in the professional qualification that results in lower income and unemployment; this would be more of a motivation to persist in alcoholism, even as a way to escape from reality. The performance of women in social work is considered a factor to lower contribution in alcohol intake. However, they are not sufficient to prevent their consumption (Nóbrega \& Oliveira, 2005).

Regarding to race, more studies are needed to analyse this aspect in greater depth. The observed association between alcohol consumption and women's skin-color highlighted higher prevalence among those who self-classified as white is reaffirmed in recent studies, but it is not clear in the literature. It is known that black and brown people tend to be more economically susceptible and people with higher purchasing power are more vulnerable to substance use, since there is more financial availability, so their income factor could explain this relationship (Silva, Oliveira, \& Souza, 2016).

The abandonment of treatment observed in this study is congruent with literary findings. Treatment is usually seen in the context of chronic diseases requiring prolonged follow-up and it is not uncommon to find high drop-out rates in the first month of treatment (Elbreder et al., 2008).

Assistance to these women should not be restricted to drug treatment alone. There is a need for interaction between different therapeutic interventions. At CEAAD, follow-ups are carried out with a team of psychologists, occupational therapists, social workers and nurses. 
Due to the fact that it is a retrospective study based exclusively on patients' records, the limitations of this study are evident. In addition, important aspects could not be better explored, such as the type of beverage consumed, use of medications and prior treatments or psychiatric comorbidities associated with alcoholism. However, the data collected could be well analyzed contributing to the socio demographic characterization of the women under study.

There is a clear need for more research in the field. This work is the basis for a prospective study that seeks to identify various reasons related to treatment abandonment as well as to establish a proposal for primary and secondary therapeutic interventions for this population.

\section{CONCLUSIONS}

Associate women with their bio psycho social environment is a way to better propose treatment, as well as better investments in prevention. Research shows that patients are generally young adults, alone and without employment. The degree of severe dependence, independently of treatment abandonment, prevailed in the studied population.

These women are inserted in a precarious social and economic reality. During treatment, it is important that professionals address the various spheres of these women's life. It is important to understand psychosocial dynamics, so there can be reformulations in the types of care provided to these patients, as well as to propose and stimulate the adoption of public health preventive actions.

There is need to carry out studies that address the innumerous variables to be considered in public policies regarding coping with such difficulties as well as strategies for prevention and / or treatment of this problem. In this way, it will be possible to establish effective and structured interventions to improve life quality for the studied population.

\section{REFERENCES}

1. Baekeland, F., \& Lundwall, L. (1975). Dropping out of treatment: a critical review. Psychological Bulletin, 82(5), 738-783. http://dx.doi. org/10.1037/h0077132.

2. Elbreder, M. F., Laranjeira, R., Siqueira, M. M., \& Barbosa, D. A. (2008). Perfil de mulheres usuárias de álcool em ambulatório especializado em dependência química. Brazilian Journal of Psychiatry, 57(1), 9-15. http://dx. doi.org/10.1590/S0047-20852008000100003.

3. Esper, L. H., Corradi-Webster, C. M., Carvalho, A. M. P., \& Furtado, E. F. (2013). Women in outpatient treatment for alcohol abuse: sociodemographic and clinical characteristics. Gaúcha Nursing Journal, 34(2), 93-101. http://dx.doi.org/10.1590/S1983-14472013000200012.

4. Keller M. (1980). Conceptions about alcoholism. Rev ABP APAL, 2(2), 93-100.

5. Malbergier, A., Cardoso L. R. D., \& Amaral, R. A. (2012). Uso de substâncias na adolescência e problemas familiares. Public Health Notebooks, 28(4), 678-688. http://dx.doi.org/10.1590/S0102-311X2012000400007.

6. AL-DARAJI, H. J. (2013). Effect of supplementing the diet of Japanese quail (Coturnix coturnix japonica) with sesame (Sesamum indicum) oil and seeds on egg quality characteristics. International Journal of Agricultural Science and Research (IJASR), 3(2), 245-256.

7. Mendes, M. C., Cunha, J. R. F., \& Nogueira, A. A. (2011). A mulher e o uso de álcool. Brazilian Journal of Gynecology and Obstetrics, 33 (11), 323-327. http://dx.doi.org/10.1590/S0100-72032011001100001. 
8. Ministério da Saúde. Secretaria Executiva. Coordenação Nacional de DST/Aids. (2003). A política do Ministério da Saúde para atenção integral a usuários de álcool e outras drogas. Brasília: Ministério da Saúde. Retrieved from http://bvsms.saude.gov.br/bvs/publicacoes/politica_atencao_alcool_drogas.pdf.

9. Monteiro, C. F. S., Dourado, G. O. L., Graça Júnior, C. A. G., \& Freire, A. K. N. (2011). Relatos de mulheres em uso prejudicial de bebidas alcoólicas. Anna Nery School, 15(3), 567-572. http://dx.doi.org/10.1590/S1414-81452011000300018.

10. Nóbrega, M. P. S. S., \& Oliveira, E. M. (2005). Mulheres usuárias de álcool: análise qualitativa. Journal of Public Health, 39 (5), 816-823. http://dx.doi.org/10.1590/S0034-89102005000500018.

11. Oliveira, G. C., Dell'Agnolo, C. M., Ballani, T. S. L., Carvalho, M. D. B., \& Pelloso, S. M. (2012). Consumo abusivo de álcool em mulheres. Gaúcha Nursing Journal, 33(2), 60-68. http://dx.doi.org/10.1590/S1983-14472012000200010.

12. Santos, A. M., \& Silva, M. R. S. (2012). A experiência de cuidar da mulher alcoolista na família. Revista da Escola de Enfermagem da USP, 46(2), 364-371. http://dx.doi.org/10.1590/S0080-62342012000200014.

13. Pandey, R. U., Garg, Y. G., \& Bharat, A. L. K. A. (2014). Understanding dependency of liveability on socio-economic and demographic parameters. International Journal of Humanities and Social Sciences (IJHSS), 3(1), 61-68.

14. Silva, N. A., Oliveira, J. L., \& Souza, J. (2016). Alcohol and tobacco consumption among seamstresses from the city of Formiga - Minas Gerais. SMAD. Alcohol and Drug Mental Health Electronic Journal, 12(4), 222-230. http://dx.doi.org/10.11606/issn.1806-6976.v12i4p222-230.

15. Silva, S. E. D., Vasconcelos, E. V., Padilha, M. I. C. S., Martini, J. G., \& Backes, V. M. S. (2007). A educação em saúde como uma estratégia para enfermagem na prevenção do alcoolismo. Anna Nery School, 11(4), 699-705. http://dx.doi.org/10.1590/S1414-81452007000400023. 